\title{
Mechanistic insight of predictive biomarkers for antitumor PD-1/PD-L1 blockade: A paradigm shift towards immunome evaluation (Review)
}

\author{
WENJIE YOU ${ }^{1-3}$, BIN SHANG $^{4,5}$, JIAN SUN $^{1-3}$, XUEQING LIU $^{6}$, LILI SU $^{1-3}$ and SHUJUAN JIANG ${ }^{1-3}$ \\ ${ }^{1}$ Department of Respiratory and Critical Care Medicine, Shandong Provincial Hospital, Cheeloo College of Medicine, \\ Shandong University; ${ }^{2}$ Department of Respiratory and Critical Care Medicine, Shandong Provincial Hospital \\ Affiliated to Shandong First Medical University; ${ }^{3}$ Shandong Key Laboratory of Infectious Respiratory Disease; \\ ${ }^{4}$ Department of Thoracic Surgery, Shandong Provincial Hospital, Cheeloo College of Medicine, Shandong University; \\ ${ }^{5}$ Department of Thoracic Surgery, Shandong Provincial Hospital Affiliated to Shandong First Medical University, Jinan, \\ Shandong 250021; ${ }^{6}$ Department of Respiratory and Critical Care Medicine, Ren Ji Hospital, School of Medicine, \\ Shanghai Jiao Tong University, Shanghai 200127, P.R. China
}

Received January 30, 2020; Accepted May 14, 2020

DOI: $10.3892 /$ or.2020.7643

\begin{abstract}
Checkpoint inhibitor-based immunotherapy has exhibited unprecedented success in the treatment of advanced-stage cancer in recent years. Several therapeutic antibodies targeting programmed death-1 (PD-1) or its ligand (PD-L1) have received regulatory approvals for the treatment of multiple malignancies, including melanoma, non-small cell lung cancer, kidney cancer and Hodgkin's lymphoma. However, a substantial proportion of patients still do not benefit from these agents, let alone the risk of immune-associated toxicities and financial burden. Therefore, it is imperative to identify valid predictive biomarkers which can help optimize the selection of patients. In this review, a mechanism-based interpretation of tumor PD-L1 expression and other candidate biomarkers of response to antitumor PD-1/PD-L1 blockade was provided, particularly for the tumor microenvironment-derived 'immunomes', and the challenges faced in their clinical use was addressed. Directions for future biomarker development and the potential of combined biomarker strategies were also proposed.
\end{abstract}

Correspondence to: Professor Shujuan Jiang or Professor Lili Su, Department of Respiratory and Critical Care Medicine, Shandong Provincial Hospital, Cheeloo College of Medicine, Shandong University, 324 Jingwu Road, Jinan, Shandong 250021, P.R. China E-mail: docjiangshujuan@163.com

E-mail: sulili801@126.com

Key words: anti-PD-1/PD-L1 immunotherapy, PD-L1, tumor mutational burden, tumor microenvironment, combined biomarker strategies

\section{Contents}

1. Introduction

2. PD-1/PD-L1-maintained immune tolerance

3. Predictive biomarkers of response to anti-PD-1/PD-L1 therapy

4. Future biomarker considerations

5. Conclusions

\section{Introduction}

Cancer immunotherapy, which aims to foster the host immune response against cancer to obtain durable anticancer responses, has achieved marked success in the past decade (1). The programmed death-1 (PD-1)-PD ligand-1 (PD-L1) receptor-ligand pair is an important immune checkpoint pathway exploited by tumor cells to evade immune attack (2). Blockade of the PD-1/PD-L1 axis represents an effective form of cancer immunotherapy (3). To date, several anti-PD-1/PD-L1 antibodies have been designed and assessed in clinical trials for cancer treatment. Nivolumab and pembrolizumab are humanized, engineered anti-PD-1 monoantibodies that have demonstrated durable objective response and improved overall survival in patients with advanced melanoma or non-small cell lung cancer (NSCLC), supporting their approved applications in these cancer types (4-10). Nivolumab also exhibited marked therapeutic activity in patients with metastatic renal cell carcinoma (RCC) or relapsed/refractory Hodgkin's lymphoma $(11,12)$. In addition to anti-PD-1 drugs, there are numerous agents targeting PD-L1 in clinical development at various phases. Atezolizumab, a monoclonal antibody against PD-L1, was approved for the treatment of metastatic bladder carcinoma and NSCLC, based on a prolonged overall survival compared with chemotherapy $(13,14)$. Another recent phase Ia study revealed the potential antitumor activity of atezolizumab in metastatic RCC (15). Other anti-PD-L1 antibodies, such as 
durvalumab and avelumab, have been launched for the treatment of advanced NSCLC, urothelial cancer and Merkel cell carcinoma.

Despite significant progress of PD-1/PD-L1-directed immunotherapy, the efficacy and safety profiles of these agents varies greatly across individual patients and among different tumor types. Not all patients respond to PD-1/PD-L1 blockade $(5,8,9,15)$. Moreover, immune checkpoint inhibitors (ICIs) may have immune-associated adverse events and are usually costly $(16,17)$. Thus, it is of utmost value to define predictive biomarkers of response, in order to optimize the application of anti-PD-1/PD-L1 ICIs. The detection of tumor-cell PD-L1 expression via immunohistochemistry (IHC) has been thus far the most widely studied biomarker for predicting response to anti-PD-1/PD-L1 immunotherapy. However, a variety of limitations have been found with the PD-L1 testing, such as different antibodies, different analysis systems and different cut-off criteria for positivity in previous clinical trials, and the heterogeneity of PD-L1 expression between serial sections of one tumor sample $(18,19)$. While tumor PD-L1 expression is predictive of response to $\mathrm{PD}-1 / \mathrm{PD}-\mathrm{L} 1$ inhibitors, a small fraction of PD-L1-negative patients can also benefit from PD-1/PD-L1 blockade $(6,9,20,21)$. There is an urgent need to develop alternative biomarkers to identify patients who are most likely to respond. This review provides an overview of the mechanisms of action of the established PD-L1 testing and other evolving biomarkers to predict the response to anti-PD-1/PD-L1 therapies. The review also details the challenges faced by the application of predictive biomarkers, and proposes directions for future biomarker development and combined biomarker strategies. This review represents the latest evidence regarding biomarkers of response to PD-1/PD-L1 blockade for cancer treatment.

\section{PD-1/PD-L1-maintained immune tolerance}

Immune tolerance is considered one of the hallmarks of cancer that is exploited by tumor cells to evade immune surveillance and elimination (22) (Fig. 1). In general, antigen presenting cells (APCs) in lymphoid tissue can dispose and present mutant or non-mutant neoantigens to $\mathrm{CD}^{+}$and $\mathrm{CD} 8^{+}$ $\mathrm{T}$ cells for priming via the interaction between major histocompatibility complex (MHC) II and T-cell receptor (TCR). The $\mathrm{CD}^{+} \mathrm{T}$ helper cells also contribute to the priming of $\mathrm{CD}^{+} \mathrm{T}$ cytotoxic cells via various cytokines. Both $\mathrm{CD} 4^{+}$ and $\mathrm{CD}^{+} \mathrm{T}$ cells are subsequently activated by the APCs through B7.1/B7.2/CD28 co-stimulatory pathways, which trigger their proliferation, migration to tumor sites, secretion of inflammatory cytokines and cytotoxic activities, leading ultimately to tumor eradication (23). There are multiple mechanisms of immune tolerance in tumors, including the well-established B7.1/B7.2/cytotoxic T-lymphocyte-associated antigen-4 (CTLA-4) and PD-L1/PD-L2/PD-1 checkpoint pathways (24). PD-1 is an inhibitory receptor found on activated $\mathrm{T}$ and $\mathrm{B}$ cells, natural killer cells and monocytes, while its main ligand, PD-L1, is expressed on tumor cells, dendritic cells, macrophages, stromal cells and activated T cells (25). Another ligand PD-L2 is mostly restricted to APCs, such as dendritic cells and monocytes (26). The mechanism of action is that PD-L1 results in the tyrosine phosphorylation of PD-1 cytoplasmic immunoreceptor tyrosine-based inhibition motif (ITIM) and immunoreceptor tyrosine-based switch motif (ITSM), which recruit phosphatases, particularly Src homology region 2 domain-containing phosphatase-2 (SHP-2) (27). This leads to the dephosphorylation of TCR proximal signaling molecules, such as ZAP70, PKC $\theta$ and CD38, attenuating TCR and CD28 signals, which ultimately promotes $\mathrm{T}$ cell apoptosis, anergy and functional exhaustion (28).

\section{Predictive biomarkers of response to anti-PD-1/PD-L1 therapy}

PD-L1 expression. PD-L1 expression in tumors has been hypothesized to be associated with response to PD-1/PD-L1 blockade. In a phase I trial, Topalian et al firstly demonstrated an association between PD-L1 expression in tumor cells and objective response to nivolumab in multiple cancer types (16). They determined surface PD-L1 expression of pretreated tumor samples via IHC, with a cut-off value of 5\% defined to be PD-L1-positive, and found that 9 out of 25 PD-L1-positive patients had an objective response to nivolumab, while none of the 17 PD-L1-negative patients had an objective response. The KEYNOTE-024 study revealed superior progression-free survival (PFS) and overall survival (OS) in a pembrolizumab treatment group vs. a platinum-doublet chemotherapy group in patients with advanced NSCLC and PD-L1 expression in at least $50 \%$ of tumor cells (29). Thus far, several clinical trials have been performed to compare the treatment efficiency of anti-PD-1/PD-L1 antibodies between PD-L1-positive and -negative tumors (6-11,17,21,30-43), which are summarized in Table SI. Despite different pretreatments and cut-off points to define PD-L1 positivity, these studies have largely supported a role for PD-L1 expression, either on tumor cells or on tumor-infiltrating immune cells, as a predictive biomarker of response to PD-1/PD-L1 blockade in a variety of tumors. Notably, by analyzing multiple tumor types, Taube et al determined that membranous PD-L1 expression by tumor cells and infiltrating immune cells was most abundant in melanoma, NSCLC and RCC; tumors that exhibit objective response to anti-PD-1 immunotherapy (44).

In addition to PD-L1 expression on tumor cells or tumor-infiltrating immune cells, other forms of PD-L1 can also predict response to anti-PD-1/PD-L1 therapy. A recent study by Chen et al revealed the presence of PD-L1 on the surface of exosomes released by melanoma cells (45). They found that a fold change in circulating exosomal PD-L1 $>2.43$ at weeks 3-6 was associated with an improved objective response rate (ORR), PFS and OS to pembrolizumab. Another study of NSCLC suggested that the baseline plasma soluble PD-L1 concentration, determined using the enzyme-linked immunosorbent assay method, was significantly associated with clinical benefit in nivolumab therapy (46). However, lower response rate and shorter OS were detected in patients with NSCLC and high plasma-soluble PD-L1 levels.

In numerous tumors, PD-L1 expression can be induced either via oncogenic drivers and transcriptional factors, or via cytokines produced by tumor-infiltrating immune cells (47). Thus, PD-L1 acts as a constitutive and adaptive immune resistance against antitumor immune responses. The predictive 


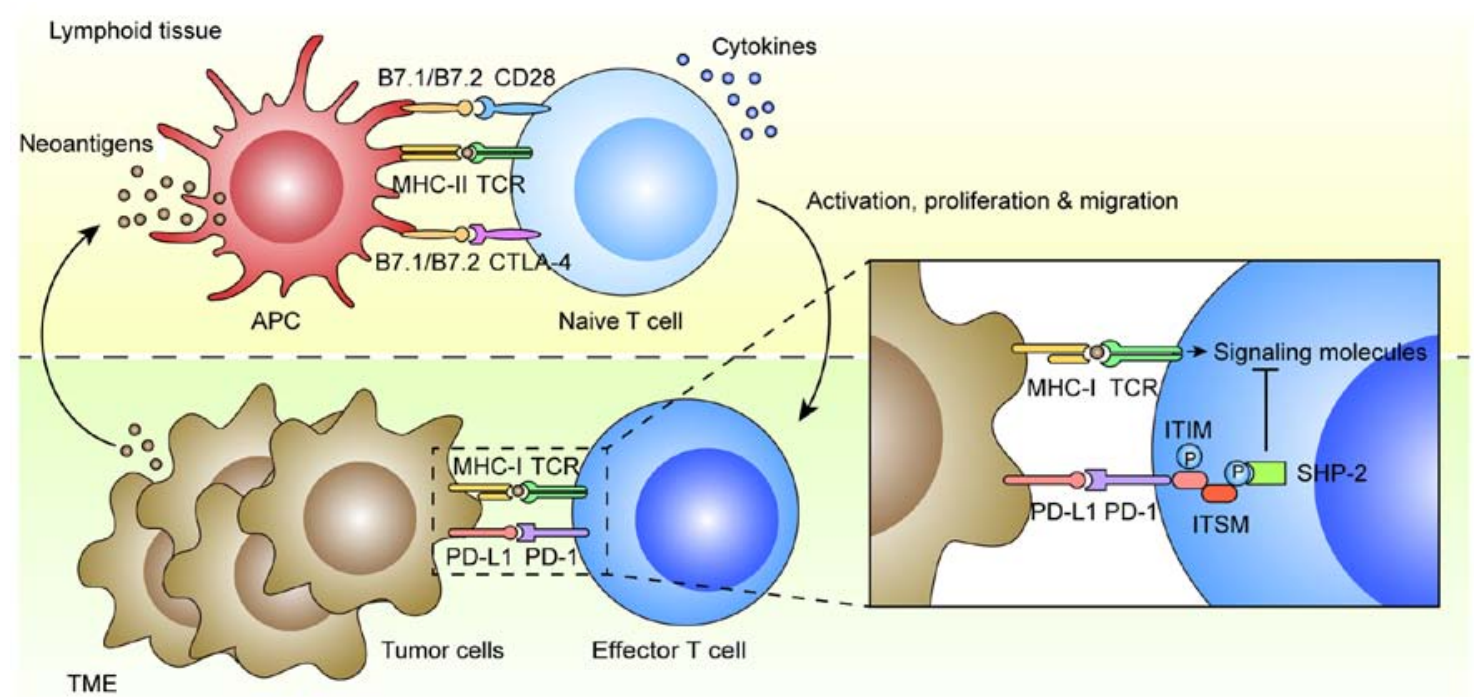

Figure 1. PD-1/PD-L1-maintains immune tolerance in tumors. In lymphoid tissue, APCs can dispose neoantigens, and then activate naive T cells through MHC-II/TCR interaction and B7.1/B7.2/CD28 co-stimulatory pathways. The CD4+ $\mathrm{T}$ helper cells can also contribute to the priming of $\mathrm{CD} 8^{+} \mathrm{T}$ cytotoxic cells via various cytokines. In early stages of $\mathrm{T}$ cell activation, the T-cell response can be downregulated by B7.1/B7.2/CTLA-4 checkpoint pathways. The effector $\mathrm{T}$ cells can proliferate and migrate to TME, leading to tumor eradication via MHC-I/TCR interaction. The PD-1/PD-L1 checkpoint pathway can maintain immune resistance of tumor cells to T-cell attack. The mechanism of action is that PD-L1 results in the tyrosine phosphorylation of PD-1 cytoplasmic ITIM and ITSM in effector T cells, which recruit phosphatases, particularly SHP-2. This leads to the dephosphorylation of TCR proximal signaling molecules, attenuating TCR and CD28 signals, which promotes T-cell apoptosis, anergy and functional exhaustion. PD-1, programmed death-1; PD-L1, PD ligand-1; APCs, antigen presenting cells; MHC, major histocompatibility complex; TCR, T cell receptor; CTLA-4, cytotoxic T lymphocyte-associated antigen-4; TME, tumor microenvironment; ITIM, immunoreceptor tyrosine-based inhibition motif; ITSM, immunoreceptor tyrosine-based switch motif; SHP-2, Src homology region 2 domain-containing phosphatase-2.

value of PD-L1 expression can be explained by the fact that inhibiting the PD-1/PD-L1 axis with therapeutic antibodies allows the host to overcome immune resistance and thereby activate the antitumor immunity.

Although the results suggest PD-L1 expression as a predictive biomarker, several clinical trials have repeatedly demonstrated that there is a small but definite proportion of PD-L1-negative patients who can also derive clinical benefit from PD-1/PD-L1 blockade $(6,9,20,21)$. As summarized in Table SI, ORR to PD-1/PD-L1 antibodies in PD-L1-negative groups was revealed to be $20-40 \%$ in melanomas, $10-20 \%$ in NSCLC, and 5-20\% in urothelial carcinomas. Brahmer et al even observed similar ORRs and survival outcomes between patients with PD-L1-positive and -negative squamous-cell NSCLC treated with second-line nivolumab, collectively revealing that there should be predictive biomarkers other than PD-L1 expression that can also determine the efficacy of PD-1/PD-L1 inhibitors (9). PD-L1 testing alone is insufficient for the selection of patients for anti-PD-1/PD-L1 immunotherapy. On the other hand, several studies indicated that anti-PD-L1 is somewhat less effective than anti-PD-1 therapy, which may be associated with slightly lower toxicity in cancer treatment $(16,48)$. This discrepancy is potentially due to the mode of action, targeting the ligand vs. the receptor, between anti-PD-1 and anti-PD-L1 antibodies. Consistently, our data also revealed that anti-PD-1 therapy, but not anti-PD-L1, was effective against FXR ${ }^{\text {high }}$ PD-L1 ${ }^{\text {low }}$ mouse Lewis lung carcinoma (LLC) tumors. It speculated that the absence of targetable PD-L1 on tumor cells may be responsible for the ineffectiveness of anti-PD-L1 antibody (49). To date, no clinical trials have directly compared the treatment efficiency and toxicity between anti-PD-1 and
anti-PD-L1 antibodies, particularly in PD-L1-low/negative patients.

Notably, the application of PD-L1 testing via IHC as a predictive biomarker is associated with several issues. Technically, different PD-L1 IHC antibodies with different analysis systems and different cut-off values for PD-L1 positivity were employed in early clinical trials (Table SI). The anti-PD-L1 28-2 clone and 22C 3 clone were, thus far, the most prevalent antibodies for IHC. The common thresholds for PD-L1 positivity were 1, 5 and $10 \%$ in multiple cancer types (Table SI). Encouragingly, recent studies have compared three PD-L1 diagnostic assays (Dako 28-8, 22C3 and Ventana SP263), revealing preferable concordance rates at various cut-offs in resected NSCLC samples $(50,51)$, and great efforts have been paid to develop a consensus for the use of PD-L1 IHC testing as a predictive biomarker for anti-PD-1/PD-L1 immunotherapy (52). Essentially, the expression of PD-L1 on tumor cells and infiltrating immune cells is dynamic. It has been discovered that PD-L1 expression levels can be influenced by various mechanisms, including the change in intracellular transcriptional factors or extracellular inflammatory cytokines, as well as antitumor therapies, such as radiation therapy, chemotherapy and targeted therapy (53-62). Recently, we detected an inverse correlation between FXR and PD-L1 expression in a cohort of NSCLC specimens (49). Our data demonstrated that FXR could directly bind to an FXR-responsive element in $P D-L 1$ promoter and repress its transcription, suggesting FXR as a novel transcriptional factor for the regulation of PD-L1. In general, contemporaneous tumor samples, obtained at the beginning of immune checkpoint blockade (ICB), should represent the PD-L1 expression status better compared with archival tumor samples. Another ineluctable variable is the heterogeneity 
of PD-L1 expression, which exists both within the same tumor lesion, and between primary and metastatic lesions in the same patient. It has been reported that PD-L1 expression is widely heterogeneous within the tumor, which often accumulates at the tumor-immune interface (44). Takamori et al compared PD-L1 expression between lung metastases and corresponding primary tumors, including tumors in the rectum, colon, liver and bile duct. Although the proportion of PD-L1-positive tumor cells was not significantly different between lung metastases and primary tumors, PD-L1 expression on immune cells was significantly higher in lung metastases compared with the corresponding primary tumors (63). In this regard, tumor sampling aimed at a particular proportion of one tumor site may not accurately reflect on the PD-L1 status of that patient. Finally, factors enabling the prediction of response, such as tumor mutational burden (TMB) and the tumor microenvironment (TME), should be incorporated with PD-L1 IHC staining, in order to achieve a paradigm of precise anti-PD-1/PD-L1 immunotherapy.

Tumor mutational burden. Owing to advances in DNA sequencing techniques, a large amount of information on cancer genetics and genomics has been gained in the past few decades. There is increasing evidence that the TMB can predict response to ICIs, including anti-PD-1/PD-L1 drugs. The first indication was from the combined result, revealing that tumors with a high TMB (melanoma and NSCLC) often have a higher response rate to anti-PD-1 or anti-PD-L1 therapy across multiple tumor types (16,48,64-66). Moreover, within certain tumors, Rizvi et al revealed that patients with NSCLC and a high non-synonymous TMB exhibited durable clinical benefit to pembrolizumab, defined as a partial or stable response rate, for $>6$ months, compared with patients with less frequent non-synonymous mutations (67). Consistently, a pilot study of nivolumab in early-stage NSCLC revealed a significantly higher mean TMB in tumors with a major pathological response compared with tumors without a major pathological response (68). Recently, Wang et al reported that a higher blood TMB (bTMB), established by a 150 -cancer gene panel of circulating tumor DNA, was significantly associated with superior PFS and ORR in patients with NSCLC treated with anti-PD-1 and anti-PD-L1 drugs (69), collectively suggesting the potential predictive value of TMB in antitumor PD-1/PD-L1 blockade.

Notably, recent evidence suggests that mismatch repair deficiency (MMRD) may be associated with an increased response to PD-1/PD-L1 blockade (70). Mismatch repair (MMR) is an intrinsic mechanism that can identify and correct errors in DNA replication and recombination, such as miss-incorporation deletions and base insertions (71). Mutations in MMR genes can produce log-fold increase of TMB, leading to the detectable DNA microsatellite instability (MSI) (23). It was estimated that tumors with a MMRD genotype possess 10 to 100 -fold the mutational load of their MMR-proficient counterparts (23). Le et al have formally evaluated the predictive value of MMRD in patients with colorectal and non-colorectal cancer treated with pembrolizumab, and revealed that patients with MMRD colorectal cancer had a significantly improved ORR and PFS rate compared with those with MMR-proficient colorectal cancer (72). Moreover, it was demonstrated that the immune-associated ORR and PFS rate of pembrolizumab treatment were similar between MMRD colorectal cancers and MMRD non-colorectal cancers. Whole-exome sequencing revealed a mean of 1782 somatic mutations per tumor in MMRD tumors compared with 73 in MMR-proficient tumors; however, there were in total 41 cases in this phase II trial. Subsequently, the study was expanded to 86 patients of 12 tumor types with MMRD, which displayed an objective radiographic response rate of $53 \%$ and a complete response rate of $21 \%$ to anti-PD-1 therapy, although the median PFS and OS were not reached (73). Large clinical studies are required to verify the potential of MMRD or MSI in predicting the response to different PD-1/PD-L1 antibodies within different tumor types.

The association between $\mathrm{TMB}$ and response to anti-PD-1/PD-L1 drugs is considered to be primarily due to the generation of neoantigens, as a result of somatic mutations in tumor cells. The theory is that tumors with a high mutational load often possess more neoantigens, which can be recognized as non-self epitopes by the immune system, thereby enhancing $\mathrm{T}$ cell responses against tumors, as well as killing tumor cells when the PD-1/PD-L1 axis is blocked (74). It has been documented that the sensitivity to PD-1 blockade in advanced NSCLC and melanoma was increased in tumors enriched for clonal neoantigens (75). In parallel, active $\mathrm{T}$ cells against clonal neoantigens were detected in tumors with durable clinical benefits. Another study revealed a significant correlation between higher neoantigen burden and improved treatment efficacy in patients with NSCLC treated with pembrolizumab (67). In addition, the increased PD-L1 expression in the context of certain mutations is proposed as another determinant. A recent study demonstrated that the activating mutations in Janus kinase 3 (Jak3) promoted PD-L1 expression in lung cancer cells and the tumor immune microenvironment, thus contributing to the durable clinical benefit from anti-PD-L1 therapy (76). To date, a variety of oncogenic mutations, such as EGFR, PTEN and ALK, have been reported to be associated with PD-L1 upregulation in tumor cells, although further investigation is required to better define the role of PD-L1 in TMB-associated response to anti-PD-1/PD-L1 immunotherapy (77-79). In this respect, it is also reasonable to speculate that the somatic mutations in tumor cells would have a broad effect on the tumor immune microenvironment; specifically, those affecting other immune checkpoints, cytokines and chemokines that may also determine anti-PD-1/PD-L1 therapeutic response. Further studies are warranted for a comprehensive examination of host immune make-up in tumors with somatic mutations in comparison with others.

TMB is a promising predictive biomarker, albeit with its own limitations. Although a number of studies correlate TMB with tumor response to anti-PD-1/PD-L1 drugs, there has been thus far, seldom numerical cut-off value of TMB that was formally defined $(16,39,48,66,68)$. Rizvi et al established a cut-off point of 178 non-synonymous mutations per sample to predict durable clinical benefit in a discovery cohort of NSCLC treated with pembrolizumab (67). In the validation set, this cut-off point yielded a clinical benefit rate of $75 \%$ in patients harboring at least 178 mutations, compared with $14 \%$ in patients with $<178$ mutations. Another clinical trial defined 
$\geq 10$ mutations per megabase in DNA sequences of tumor cells as high TMB (34). Moreover, while somatic mutations in tumor cells may produce neoantigens that are prone to immune attack, not all neoantigens can elicit a T-cell response. A previous study has revealed that only $10 \%$ of non-synonymous point mutations of an MC38 mouse tumor model could generate peptides capable of binding to MHC-I with high affinity, and only a proportion of these peptides, rather than the overall peptide load, were necessary to elicit immunogenicity (80). Despite recent technological advances, for example, whole exome sequencing or computational algorithm, it is still challenging to identify meaningful neoantigens that are responsible for T-cell responses. In addition, intratumor mutation heterogeneity should be another obstacle for predicting response to PD-1/PD-L1 blockade. McGranahan et al detected considerable intratumor neoantigen heterogeneity within NSCLC tumors (75). It was demonstrated in the same study that decreased intratumor neoantigen heterogeneity was correlated with improved OS of patients with lung adenocarcinoma. Therefore, mutations that arise early and are shared by most cancer cells in an individual should elicit more potent antitumor T-cell responses compared with mutations that arise later or are limited to a fraction of cancer cells. Lastly, several studies revealed primary resistance to anti-PD-1/PD-L1 in tumors with specific mutations, for example $L K B 1$ loss, which may be ascribed to the impaired antitumor immune responses $(81,82)$.

Tumor microenvironment. The TME consists of non-malignant stromal cells, such as cancer-associated fibroblasts (CAFs), bone marrow-derived cells and tumor-infiltrating immune cells, extracellular matrix, and the blood and lymphatic vascular networks (83). The tumor-infiltrating immune cells include macrophages, dendritic cells, natural killer cells, $\mathrm{B}$ cells, effector $\mathrm{T}$ helper cells, regulatory $\mathrm{T}$ cells (Treg) and cytotoxic $\mathrm{T}$ cells. The stromal cells aforementioned can release growth factors, matrix-degrading enzymes, cytokines and chemokines, responsible for either antitumor immune response or immunosuppressive response $(84,85)$. In addition, both activating markers, such as MHC-II and CD86, and exhausting markers, such as PD-1, CTLA-4, LAG-3 and TIM-3, can be expressed in tumor-infiltrating immune cells, which collectively form a complex host of factors to either combat or promote tumor progression (86). Previous studies have revealed that the response of tumor cells to anti-PD-1/PD-L1 therapy is determined not only by intrinsic properties of tumor cells but also by cellular and molecular components of TME $(87,88)$.

Firstly, the presence of tumor-infiltrating $\mathrm{T}$ cells was demonstrated to be associated with clinical benefit from anti-PD-1/PD-L1 therapy. Tumeh et al analyzed tumor samples from 46 patients with metastatic melanoma treated with pembrolizumab (89). Higher numbers of CD8-, PD-1- and PD-L1-expressing $T$ cells were found at the invasive tumor margin and inside tumors in responding patients compared with non-responders. Ultimately, it was validated that the presence of $\mathrm{CD}^{+} \mathrm{T}$ cells at the invasive tumor margin serves as a potential predictive biomarker to anti-PD-1 therapy in melanoma. Chen et al revealed a modest association between $\mathrm{CD}^{+}, \mathrm{CD}^{+}$and $\mathrm{CD} 45 \mathrm{RO}^{+} \mathrm{T}$ cells in pretreated tumor samples and responsiveness to PD-1 blockade in patients with advanced melanoma (90). Notably, this association became more significant after anti-PD-1 therapy. Another study on melanoma found that an increasing proportion of PD- $1^{\text {high }}$ CTLA- $4^{\text {high }}$ subset within tumor-infiltrating $\mathrm{CD} 8^{+} \mathrm{T}$ cells strongly correlated with objective response to anti-PD-1 therapy (91). In contrast, PD-1 $1^{+}$tumor-infiltrating T cells were significantly decreased in brain metastatic lesions compared with primary lung cancer, which was associated with a lower likelihood of objective response to anti-PD-1 in brain metastases (92). Consistently, our study revealed that aside from the downregulated PD-L1 expression, enforced FXR expression generated an immunosuppressive microenvironment in mouse LLC tumors, characterized by the inactivated and exhausted $\mathrm{CD}^{+} \mathrm{T}$ cells (shown as decreased $\mathrm{TNF}^{+} \mathrm{CD}^{+} \mathrm{T}$ cells, as well as increased LAG-3 expression on $\mathrm{CD}^{+} \mathrm{T}$ cells), which was correlated with significant tumor growth inhibition in FXR-overexpressed LLC tumors treated with anti-PD-1 antibody (49). These findings collectively suggested that pretreated tumor-infiltrating $\mathrm{T}$ cells, particularly for the exhausted $\mathrm{CD}^{+} \mathrm{T}$ cells, can act as a promising predictive biomarker for PD-1/PD-L1 blockade (Fig. 2). This phenomenon can be logically ascribed to the pre-existing $\mathrm{T}$ cell-mediated antitumor immunity, which is restrained by the PD-1/PD-L1-induced suppression, but can be reactivated via PD-1/PD-L1 blockade. However, it was also proposed that intratumor $\mathrm{T}$ cells expressing multiple exhaustion markers may be irresponsive to anti-PD-1/PD-L1 drugs (93). Kim et al reported that VEGF-A could induce transcription factor TOX expression in T cells to drive exhaustion-specific transcription program, accounting for the resistance to PD-1 blockade in microsatellite-stable colorectal cancer (94). Another study even defined a threshold for PD-1 downregulation on tumor-infiltrating $\mathrm{CD} 8^{+} \mathrm{T}$ cells, for which the release of adaptive immune resistance could be achieved via PD-1 blockade (95). It was revealed that the functionality of PD- $1^{\text {high }}$ $\mathrm{T}$ cells in resistant tumors failed to be rescued by anti-PD-1 therapy. All these lend credence to the theory that the less exhausted tumor-infiltrating $\mathrm{CD} 8^{+} \mathrm{T}$ cells, rather than the over-exhausted populations, are probably the determinants of response to anti-PD-1/PD-L1 immunotherapy. A future area of research should be to evaluate the predictive value of exhausted $\mathrm{CD}^{+} \mathrm{T}$ cells, of various phenotypes within TME, in PD-1/PD-L1-based immunotherapy.

Secondly, the immunosuppressive cell populations in TME could restrain the response to PD-1/PD-L1 blockade (Fig. 2). It has been documented that tumor-infiltrating myeloid cells and Treg cells are partially responsible for the development of anti-PD-1 resistance in mouse colorectal and mammary cancer (95). Davis et al revealed that the functional inhibition of myeloid-derived suppressor cells (MDSCs) could enhance the objective response to anti-PD-L1 treatment in T cell-inflamed mouse tumor models of head and neck cancers (96). In a transgenic mouse model of neuroblastoma, Mao et al revealed that while checkpoint inhibitors were insufficient in controlling mouse neuroblastoma growth, combining suppressive myeloid cell inhibitor with anti-PD-1/PD-L1 antibodies resulted in superior tumor control (97). In this regard, the inhibition of immunosuppressive cell subsets within TME represents a potential predictive biomarker or rational approach to enhance antitumor PD-1/PD-L1 blockade. 


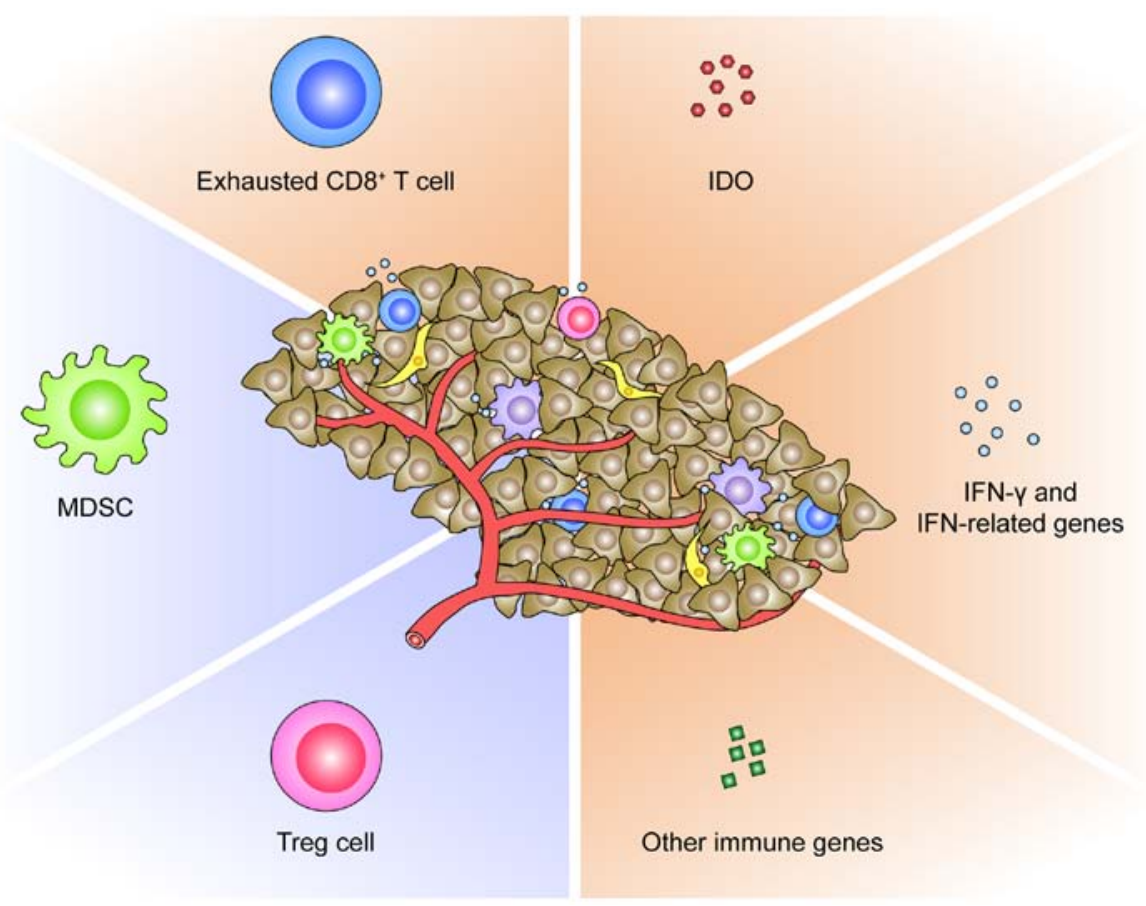

Figure 2. TME-derived predictive biomarkers for PD-1/PD-L1 blockade. The TME consists of non-malignant stromal cells (cancer-associated fibroblasts, MDSCs, effector T helper cells, cytotoxic T cells, Treg cells and macrophages), extracellular matrix, and the blood and lymphatic vascular networks. Those stromal cells can release growth factors, matrix-degrading enzymes, cytokines and chemokines. The components of TME, including exhausted CD8+ T cells, MDSCs, Treg cells, IDO, IFN- $\gamma$ and IFN-related genes (CXCL9, CXCL11, and IFN receptor-associated Jak1 and Jak2), and other immune genes (BACH2 and CCL3), proposed as biomarkers of response to anti-PD-1/PD-L1 therapy were categorized. TME, tumor microenvironment; PD-1, programmed death-1; PD-L1, PD ligand-1; MDSCs, myeloid-derived suppressor cells; Treg cells, regulatory T cells; IDO, indoleamine 2,3-dioxygenase; IFN, interferon; CXCL, C-X-C motif chemokine; Jak, Janus kinase; BACH2, BTB domain and CNC homolog 2; CCL, C-C motif chemokine.

Thirdly, the molecular profiles of TME pre- or post-antiPD-1/PD-L1 immunotherapy represent alternative biomarkers of response (Fig. 2). Indoleamine 2,3-dioxygenase (IDO), a rate-limiting enzyme in the degradation of tryptophan via the kynurenine pathway, plays a critical role in suppressing T-cell immunity within tumors (98). A recent study revealed that MSI colorectal cancer overexpressing IDO were more responsive to anti-PD-1 treatment compared with microsatellite-stable cancer (99). The IFN-related genes are also relevant in patient selection for anti-PD-1/PD-L1 therapies. In a phase I/II study of durvalumab, an ORR of $33 \%$ was revealed in NSCLC patients positive for IFN- $\gamma$ mRNA and $8 \%$ in those negative for IFN- $\gamma$ mRNA (100). Consistently, in another study on atezolizumab, pretreatment melanoma samples from responding patients had increased expression of IFN- $\gamma$ and IFN-related genes compared with non-responding samples (66). In contrast, Zaretsky et al revealed that defects in IFN receptor signaling pathways resulted in acquired resistance to anti-PD-1 therapy in melanoma (81). In addition, in a study characterizing the gene expression profiles of RCC treated with anti-PD-1 antibodies, immune genes such as $\mathrm{BACH} 2$, a regulator of $\mathrm{CD}^{+} \mathrm{T}$ cell differentiation, and $C C L 3$ involved in leukocyte migration were revealed to be overexpressed in responding patients as compared with non-responders (101). Chen et al analyzed immune signatures in longitudinal tumor samples obtained at multiple time-points during anti-PD-1 therapies, and identified numerous genes to be differentially expressed between responders and non-responders (90). However, there is thus far no conclusive data on the predictive power of either IDO, or IFN-related genes, or other immune genes in TME for anti-PD-1/PD-L1 immunotherapy.

The close association between the aforementioned TME components and treatment efficacy in PD-1/PD-L1 blockade can be explained by the following theory. Immune recognition of tumors results in a host-immune response, which promotes tumor eradication through immune mechanisms, including antigen presentation, $T$ cell priming and trafficking, cytokine production, cytotoxic activity and the expression of other immune genes. However, the antitumor $\mathrm{Th} 1$ and $\mathrm{CD} 8^{+} \mathrm{T}$ cell responses are negatively regulated by PD-1/PD-L1-mediated adaptive immune resistance (89). Other immunosuppressive constituents also contribute to the adaptive immune resistance. This is supported by the combined result, revealing that the upregulation of PD-L1 and IDO in response to IFN- $\gamma$ promotes the development of tumor-infiltrating myeloid cells and Treg cells, thereby facilitating tumor immune evasion (102-104). Response to anti-PD-1/PD-L1 immunotherapy occurs primarily in cancer patients with a T cell-inflamed but adaptive immune-resistant TME (105). In addition, the potential interactions between TME components and PD-L1 expression have partially been disclosed before. PD-L1 expression in tumors represents a negative feedback to IFN- $\gamma$ released by tumor-infiltrating immune cells, including macrophages, dendritic cells, natural killer cells, B cells and effector $\mathrm{T}$ helper cells $(56,106)$. Other immune factors within TME, such as tumor necrosis factor- $\alpha$ (TNF- $\alpha$ ), interleukin- 6 (IL-6), IL-12, IL-4, IL-10 and transforming growth 
factor- $\beta$ (TGF- $\beta$ ), have also been revealed to induce the expression of PD-L1 (57-59,107-109). In return, PD-L1 was documented to compromise the effector T-cell responses, promote the differentiation of induced Treg cells, as well as mediate the immunosuppressive activity of myeloid cells in tumors $(89,102,103)$.

Traditionally, the immune profiles of tumors can be classified into three main phenotypes: The immune-inflamed phenotype, the immune-excluded phenotype and the immune-desert phenotype; based on whether tumors harbor an inflammatory TME or not (93). In this scenario, the immune-inflamed phenotype is postulated to correlate with a higher response rate to anti-PD-1/PD-L1 therapy. Recently, a new theory arose that according to both tumor-infiltrating lymphocytes (TILs) and PD-L1 expression in tumors, the TME can be stratified into four groups: TILs PD-L1', TILs'PD-L1 ${ }^{+}$, TILs ${ }^{+} \mathrm{PD}-\mathrm{L1}^{-}$and $\mathrm{TILs}^{+} \mathrm{PD}-\mathrm{L1}^{+}$(88). While the TILs'PD-L1' group may exhibit lack of response to anti-PD-1/PD-L1 antibodies, and the TILs ${ }^{+}$PD-L1 ${ }^{-}$group is irresponsive to anti-PD-L1, the TILs ${ }^{+} \mathrm{PD}-\mathrm{L1}^{+}$group would expect the best response to anti-PD-1/PD-L1 treatments. An alternative classification of the TME immune types provided by Kondou et al was determined by the expression level of the PD-L1 and CD8b genes (110). The aforementioned stratifications should enable the selection of optimal treatment strategies for patients with cancer. More recently, the effects of TME on PD-L1 expression have attracted much attention, particularly for those with a pre-existing $\mathrm{T}$ cell-inflamed phenotype. The adaptive $\mathrm{CD} 8^{+} \mathrm{T}$ cells, CAFs, M2-like macrophages, and corresponding cytokines were revealed to engage in the dynamic change of PD-L1 within local tumors $(106,108,111)$. These findings support the predictive value of TME-derived cellular and molecular elements as a whole population, rather than in individuals, for anti-PD-1/PD-L1 immunotherapy. With the discovery of more determinants for ICB in the past decade, more attention is expected to be devoted to evaluating a spectrum of 'immunome' before anti-PD-1/PD-L1 therapies.

\section{Future biomarker considerations}

Despite the known predictive biomarkers, such as PD-L1 expression, TMB and TME profiles, additional research is still necessary to explore other reliable candidate biomarkers for predicting the response of patients to anti-PD-1/PD-L1 therapies. In fact, emerging data have indicated future directions for biomarker development.

Immunogenic cell death. Immunogenic cell death (ICD) in tumors has been implicated in the response to PD-1/PD-L1 blockade. Recently, Zhao et al reported that irreversible electroporation could induce ICD in pancreatic ductal adenocarcinomas, which activated dendritic cells and alleviated stroma-induced immunosuppression (112). The combination of irreversible electroporation and anti-PD-1 resulted in a significantly longer median survival in mouse orthotopic pancreatic ductal adenocarcinoma models compared with mice administered either treatment alone. Another study revealed that the combination of cisplatin and high-dose crizotinib induced ICD in NSCLC cells, which synergized with anti-PD-1 to induce a superior cure rate and long-term survival in mouse orthotopic NSCLC models (113). It is considered that the dying tumor cells may function as tumor vaccines to stimulate antitumor immune responses during ICD.

TCR clonality. The diverse T-cell repertoire, corresponding to different antigenic peptides bounding to class I or II MHC, is generated by random recombination of discrete TCR- $\alpha \beta$ gene segments (114). Tumeh et al analyzed tumor samples from 46 patients with metastatic melanoma obtained before and during anti-PD-1 therapy (89). It was revealed that patients who met the criteria for radiographic response had more than 10 times as many TCR clones expansion after pembrolizumab treatment, suggesting that the TCR clonality may represent a promising on-treatment predictive biomarker for anti-PD-1 therapies. The predictive value of TCR clonality during anti-PD-1 can be interpreted as an enrichment of a diverse T-cell repertoire, which will eventually be tailored as antigenic peptides on MHC interaction with TCR, reflecting an activated immune response against tumor cells (115).

Gut microbiome. Recently, intensive studies have been conducted to dissect the impact of the gut microbiome on response to anti-PD-1/PD-L1 immunotherapy in human malignancies, including melanoma, hepatocellular carcinoma, gastric cancer and NSCLC (116-119). It has been acknowledged that patients responding to PD-1/PD-L1 blockade often harbor higher diversity of gut microbiome compared with non-responders $(116,118,119)$. This effect can be partially attributed to the ability of the gut microbiome to activate the host innate immune responses (120). In addition, subsequent studies revealed a clearer association between an intact commensal bacterial community and robust antitumor T-cell responses $(121,122)$. Other studies revealed that interventions to modulate gut bacterial profiles exhibited great promise for improving the therapeutic responses $(121,123)$. Dong et al reported that diosgenin, a natural steroidal saponin, could modulate the composition of the intestinal microbiome in melanoma-bearing mice, thereby enhancing the growth-inhibitory effect of anti-PD-1 antibody (123). Another study revealed that oral administration of Bifidobacterium collaborated with anti-PD-L1 therapy to control tumor growth in mouse melanoma models (121). Although promising, the favorable bacterial species that improve antitumor PD-1/PD-L1 blockade remain to be determined.

Peripheral blood biomarkers. The evaluation of peripheral blood could be another interesting approach. It has been reported by Weide et al that relative eosinophil count $(\geq 1.5 \%)$, relative lymphocyte count $(\geq 17.5 \%)$, LDH level ( $\leq 2.5$-fold elevation), and the absence of metastases other than soft-tissue/lung were confirmed as independent baseline characteristics associated with favorable OS in patients with melanoma treated with pembrolizumab (124). Another study reported that low neutrophil to lymphocyte ratio and absolute neutrophil count during treatment was correlated with superior objective response and treatment duration in patients with advanced NSCLC cured by PD-1/PD-L1 inhibitors (125). Similarly, data from a study on patients with advanced/metastatic melanoma treated with nivolumab or pembrolizumab revealed that patients with 


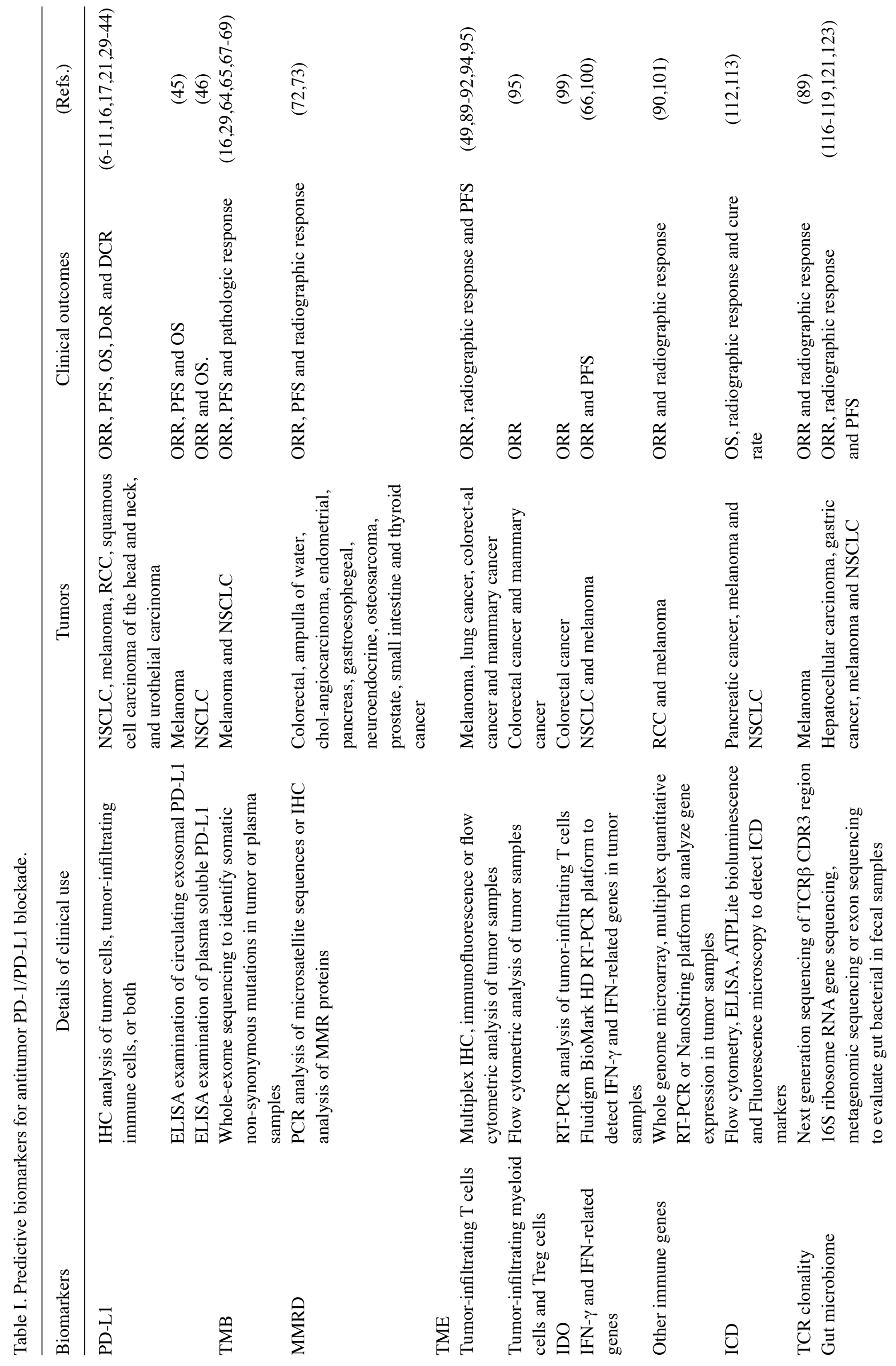


an increased baseline LDH had a significantly shorter OS compared with those with normal LDH. Furthermore, patients with a relative increase of $>10 \%$ from elevated baseline LDH during treatment had a significantly shorter OS compared with those with $\leq 10 \%$ change (126). Other parameters, such as peripheral Treg cells, antigen-specific $\mathrm{CD} 8^{+} \mathrm{T}$ cells and MDSCs, were also revealed to be associated with response to nivolumab in patients with melanoma $(21,127)$. These factors may be associated with adaptive immune resistance, which can be overcome when the PD-1/PD-L1 axis is blocked, although the detailed mechanisms need to be elucidated in future. In clinical practice, these peripheral blood biomarkers have the advantage of being readily assessable, and are suitable for serial sampling during treatment.

Imaging biomarkers. Owing to advances in technology, medical imaging can not only assess macroscopic features, but also characterize the cellular and molecular properties of malignant lesions, which may serve as a novel approach to select patients for PD-1/PD-L1 blockade. It has recently been revealed that PD-L1 and PD-1 expression in NSCLC could be quantified non-invasively with PET-CT imaging using the radiotracers ${ }^{18} \mathrm{~F}-\mathrm{BMS}-986192$ and ${ }^{89} \mathrm{Zr}$-nivolumab, respectively (128). Bensch et al conducted another first-in-human study characterizing the biodistribution of zirconium-89-labeled atezolizumab via PET within 22 patients across three tumor types (129). Notably, they found that zirconium-89-labeled atezolizumab tumor uptake was positively correlated with ORR, PFS and OS of enrolled patients treated with atezolizumab. TILs can also be traced by medical imaging. In a retrospective study by Sun et al a radiomic signature that included eight variables was established for assessing tumor-infiltrating $\mathrm{CD} 8^{+} \mathrm{T}$ cells in solid cancer types. Their data revealed that a high baseline radiomic score was associated with a higher proportion of patients who had an objective response at 3 or 6 months, as well as associated with improved OS either in univariate or in multivariate analysis (130). These imaging biomarkers were designed to detect and monitor antitumor immune activities within tumors, thereby predicting response to PD-1/PD-L1 blockade. Although just the beginning, image-driven biomarkers have the unique advantage of being non-invasive, which should make them promising candidates to aid future anti-PD-1/PD-L1 immunotherapy.

\section{Conclusions}

The clinical use, applicable tumors, as well as predicted clinical outcomes of each biomarker discussed in this review are summarized in Table I. ICIs, particularly PD-1/PD-L1-targeted antibodies, are proven to be effective in a variety of cancer types. The establishment of reliable predictive biomarkers to ensure the rational use of these agents is crucial, given the reality that only a subset of patients can benefit from PD-1/PD-L1 blockade, and that treatment with these agents carries a risk of immune-associated toxicities and substantial financial burden $(5,8,9,15)$. Conversely, based on the result of multiple validated biomarker assays, even patients who are stratified as non-responders for anti-PD-1/PD-L1 monotherapy may be treated with other 
antitumor regimens or combined treatment strategies to maximize clinical outcomes (131).

Combined biomarker strategies may enrich responders to anti-PD-1/PD-L1 immunotherapy in future. Factors enabling response prediction, such as PD-L1 IHC testing, TMB and TME profiles, should be incorporated together, since it has been indicated that high tumor PD-L1 expression does not equate to a T cell-inflamed content, and that high TMB does not always indicate pre-existing antitumor immune activities $(132,133)$. In fact, evidence has been increasingly showing that combining data from tumor immune profiling, including CD3, CD8, FoxP3, CD163, PD-L1, PD-1 and CTLA-4, could be more ideal approaches to predicting response to PD-1/PD-L1 blockade, although the optimal model has yet to be determined $(91,134)$.

Overall, anti-PD-1/PD-L1 immunotherapy is one of the predominant methods for cancer treatment. The improvement in the understanding of the interactions among multiple factors, as well as the dynamic changes of certain variables within different tumor types will certainly help identify more reliable and effective predictors for PD-1/PD-L1 blockade, thereby paving the way for a framework that allows treatment decisions to be made on a personalized basis.

\section{Acknowledgements}

Not applicable.

\section{Funding}

The present study was supported in part by grant nos. 81902325 and 81903633 from the National Natural Science Foundation of China, grant no. 2017WS026 from the Health and Family Planning Commission of Shandong Province (China), and grant nos. 2019GSF107042 and 2019GSF107051 from the Key Research and Development Plan of Shandong Province (China).

\section{Availability of data and materials}

Not applicable.

\section{Authors' contributions}

LS and SJ devised the conceptual idea. WY, BS and JS performed the literature search. WY prepared the figures. WY, XL, LS and SJ wrote, reviewed and revised the manuscript. All authors read and approved the final manuscript.

\section{Ethics approval and consent to participate}

Not applicable.

\section{Patient consent for publication}

Not applicable.

\section{Competing interests}

The authors declare that they have no competing interests.

\section{References}

1. Mellman I, Coukos G and Dranoff G: Cancer immunotherapy comes of age. Nature 480: 480-489, 2011.

2. Butte MJ, Keir ME, Phamduy TB, Sharpe AH and Freeman GJ: Programmed death-1 ligand 1 interacts specifically with the B7-1 costimulatory molecule to inhibit $\mathrm{T}$ cell responses. Immunity 27 : 111-122, 2007.

3. Zou W, Wolchok JD and Chen L: PD-L1 (B7-H1) and PD-1 pathway blockade for cancer therapy: Mechanisms, response biomarkers, and combinations. Sci Transl Med 8: 328rv4, 2016.

4. Topalian SL, Sznol M, McDermott DF, Kluger HM, Carvajal RD, Sharfman WH, Brahmer JR, Lawrence DP, Atkins MB Powderly JD, et al: Survival, durable tumor remission, and long-term safety in patients with advanced melanoma receiving nivolumab. J Clin Oncol 32: 1020-1030, 2014.

5. Robert C, Schachter J, Long GV, Arance A, Grob JJ, Mortier L, Daud A, Carlino MS, McNeil C, Lotem M, et al: Pembrolizumab versus Ipilimumab in advanced melanoma. N Engl J Med 372: 2521-2532, 2015.

6. Larkin J, Chiarion-Sileni V, Gonzalez R, Grob JJ, Cowey CL, Lao CD, Schadendorf D, Dummer R, Smylie M, Rutkowski P, et al: Combined nivolumab and Ipilimumab or Monotherapy in untreated melanoma. N Engl J Med 373: 23-34, 2015.

7. Robert C, Long GV, Brady B, Dutriaux C, Maio M, Mortier L, Hassel JC, Rutkowski P, McNeil C, Kalinka-Warzocha E, et al: Nivolumab in previously untreated melanoma without BRAF mutation. N Engl J Med 372: 320-330, 2015.

8. Borghaei H, Paz-Ares L, Horn L, Spigel DR, Steins M, Ready NE, Chow LQ, Vokes EE, Felip E, Holgado E, et al: Nivolumab versus Docetaxel in advanced nonsquamous non-small-cell lung cancer. N Engl J Med 373: 1627-1639, 2015.

9. Brahmer J, Reckamp KL, Baas P, Crino L, Eberhardt WE, Poddubskaya E, Antonia S, Pluzanski A, Vokes EE, Holgado E, et al: Nivolumab versus Docetaxel in advanced squamous-cell non-small-cell lung cancer. N Engl J Med 373: 123-135, 2015.

10. Garon EB, Rizvi NA, Hui R, Leighl N, Balmanoukian AS, Eder JP, Patnaik A, Aggarwal C, Gubens M, Horn L, et al: Pembrolizumab for the treatment of non-small-cell lung cancer. N Engl J Med 372: 2018-2028, 2015.

11. Motzer RJ, Escudier B, McDermott DF, George S, Hammers HJ, Srinivas S, Tykodi SS, Sosman JA, Procopio G, Plimack ER, et al: Nivolumab versus Everolimus in advanced renal-cell carcinoma. N Engl J Med 373: 1803-1813, 2015.

12. Ansell SM, Lesokhin AM, Borrello I, Halwani A, Scott EC, Gutierrez M, Schuster SJ, Millenson MM, Cattry D, Freeman GJ, et al: PD-1 blockade with nivolumab in relapsed or refractory Hodgkin's lymphoma. N Engl J Med 372: 311-319, 2015.

13. Powles T, Eder JP, Fine GD, Braiteh FS, Loriot Y, Cruz C, Bellmunt J, Burris HA, Petrylak DP, Teng SL, et al: MPDL3280A (anti-PD-L1) treatment leads to clinical activity in metastatic bladder cancer. Nature 515: 558-562, 2014.

14. Rittmeyer A, Barlesi F, Waterkamp D, Park K, Ciardiello F, von Pawel J, Gadgeel SM, Hida T, Kowalski DM, Dols MC, et al: Atezolizumab versus docetaxel in patients with previously treated non-small-cell lung cancer (OAK): A phase 3, open-label, multicentre randomised controlled trial. Lancet 389: 255-265, 2017.

15. McDermott DF, Sosman JA, Sznol M, Massard C, Gordon MS, Hamid O, Powderly JD, Infante JR, Fasso M, Wang YV, et al: Atezolizumab, an Anti-programmed Death-Ligand 1 antibody, in metastatic renal cell carcinoma: Long-term safety, clinical activity, and immune correlates from a phase Ia study. J Clin Oncol 34: 833-842, 2016.

16. Topalian SL, Hodi FS, Brahmer JR, Gettinger SN, Smith DC, McDermott DF, Powderly JD, Carvajal RD, Sosman JA, Atkins MB, et al: Safety, activity, and immune correlates of anti-PD-1 antibody in cancer. N Engl J Med 366: 2443-2454, 2012.

17. Fehrenbacher L, Spira A, Ballinger M, Kowanetz M, Vansteenkiste J, Mazieres J, Park K, Smith D, Artal-Cortes A, Lewanski C, et al: Atezolizumab versus docetaxel for patients with previously treated non-small-cell lung cancer (POPLAR): A multicentre, open-label, phase 2 randomised controlled trial. Lancet 387: 1837-1846, 2016.

18. Patel SP and Kurzrock R: PD-L1 expression as a predictive biomarker in cancer immunotherapy. Mol Cancer Ther 14: 847-856, 2015. 
19. McLaughlin J, Han G, Schalper KA, Carvajal-Hausdorf D Pelekanou V, Rehman J, Velcheti V, Herbst R, LoRusso P and Rimm DL: Quantitative assessment of the heterogeneity of PD-L1 expression in non-small-cell lung cancer. JAMA Oncol 2: 46-54, 2016.

20. Daud AI, Wolchok JD, Robert C, Hwu WJ, Weber JS, Ribas A, Hodi FS, Joshua AM, Kefford R, Hersey P, et al: Programmed Death-Ligand 1 expression and response to the anti-programmed Death 1 antibody pembrolizumab in melanoma. J Clin Oncol 34 4102-4109, 2016

21. Weber JS, Kudchadkar RR, Yu B, Gallenstein D, Horak CE, Inzunza HD, Zhao X, Martinez AJ, Wang W, Gibney G, et al: Safety, efficacy, and biomarkers of nivolumab with vaccine in ipilimumab-refractory or -naive melanoma. J Clin Oncol 31: 4311-4318, 2013

22. Hanahan D and Weinberg RA: Hallmarks of cancer: The next generation. Cell 144: 646-674, 2011.

23. Topalian SL, Taube JM, Anders RA and Pardoll DM: Mechanism-driven biomarkers to guide immune checkpoint blockade in cancer therapy. Nat Rev Cancer 16: 275-287, 2016.

24. Zou W: Immunosuppressive networks in the tumour environment and their therapeutic relevance. Nat Rev Cancer 5: 263-274 2005.

25. Greenwald RJ, Freeman GJ and Sharpe AH: The B7 family revisited. Annu Rev Immunol 23: 515-548, 2005.

26. Keir ME, Butte MJ, Freeman GJ and Sharpe AH: PD-1 and its ligands in tolerance and immunity. Annu Rev Immunol 26 : 677-704, 2008

27. Freeman GJ: Structures of PD-1 with its ligands: Sideways and dancing cheek to cheek. Proc Natl Acad Sci USA 105 10275-10276, 2008

28. Chemnitz JM, Parry RV, Nichols KE, June CH and Riley JL: SHP-1 and SHP-2 associate with immunoreceptor tyrosine-based switch motif of programmed death 1 upon primary human T cell stimulation, but only receptor ligation prevents $\mathrm{T}$ cell activation. J Immunol 173: 945-954, 2004.

29. Reck M, Rodriguez-Abreu D, Robinson AG, Hui R, Csoszi T, Fulop A, Gottfried M, Peled N, Tafreshi A, Cuffe S, et al: Pembrolizumab versus chemotherapy for PD-L1-positive non-small-cell lung cancer. N Engl J Med 375: 1823-1833, 2016.

30. Weber JS, D'Angelo SP, Minor D, Hodi FS, Gutzmer R, Neyns B, Hoeller C, Khushalani NI, Miller WH Jr, Lao CD, et al: Nivolumab versus chemotherapy in patients with advanced melanoma who progressed after anti-CTLA-4 treatment (CheckMate 037): A randomised, controlled, open-label, phase 3 trial. Lancet Oncol 16: 375-384, 2015.

31. Rizvi NA, Mazieres J, Planchard D, Stinchcombe TE, Dy GK, Antonia SJ, Horn L, Lena H, Minenza E, Mennecier B, et al: Activity and safety of nivolumab, an anti-PD-1 immune checkpoint inhibitor, for patients with advanced, refractory squamous non-small-cell lung cancer (CheckMate 063): A phase 2, single-arm trial. Lancet Oncol 16: 257-265, 2015.

32. Ferris RL, Blumenschein G Jr, Fayette J, Guigay J, Colevas AD Licitra L, Harrington K, Kasper S, Vokes EE, Even C, et al Nivolumab for recurrent squamous-cell carcinoma of the head and neck. N Engl J Med 375: 1856-1867, 2016.

33. Carbone DP, Reck M, Paz-Ares L, Creelan B, Horn L, Steins M, Felip E, van den Heuvel MM, Ciuleanu TE, Badin F, et al: First-line nivolumab in stage IV or recurrent non-small-cell lung cancer. N Engl J Med 376: 2415-2426, 2017.

34. Hellmann MD, Ciuleanu TE, Pluzanski A, Lee JS, Otterson GA, Audigier-Valette C, Minenza E, Linardou H, Burgers S, Salman P, et al: Nivolumab plus Ipilimumab in lung cancer with a high tumor mutational burden. N Engl J Med 378: 2093-2104, 2018 .

35. Hellmann MD, Paz-Ares L, Bernabe Caro R, Zurawski B, Kim SW, Carcereny Costa E, Park K, Alexandru A, Lupinacci L, de la Mora Jimenez E, et al: Nivolumab plus Ipilimumab in advanced non-small-cell lung cancer. $\mathrm{N}$ Engl J Med 381: 2020-2031, 2019.

36. Herbst RS, Baas P, Kim DW, Felip E, Perez-Gracia JL, Han JY, Molina J, Kim JH, Arvis CD, Ahn MJ, et al: Pembrolizumab versus docetaxel for previously treated,PD-L1-positive, advanced non-small-cell lung cancer (KEYNOTE-010): A randomised controlled trial. Lancet 387: 1540-1550, 2016.

37. Eggermont AMM, Blank CU, Mandala M, Long GV, Atkinson V Dalle S, Haydon A, Lichinitser M, Khattak A, Carlino MS, et al: Adjuvant pembrolizumab versus placebo in resected stage III melanoma. N Engl J Med 378: 1789-1801, 2018.
38. Mok TSK, Wu YL, Kudaba I, Kowalski DM, Cho BC, Turna HZ, Castro G Jr, Srimuninnimit V, Laktionov KK, Bondarenko I, et al: Pembrolizumab versus chemotherapy for previously untreated, PD-L1-expressing, locally advanced or metastatic non-small-cell lung cancer (KEYNOTE-042): A randomised, open-label, controlled, phase 3 trial. Lancet 393: 1819-1830, 2019

39. Rosenberg JE, Hoffman-Censits J, Powles T, van der Heijden MS, Balar AV, Necchi A, Dawson N, O'Donnell PH, Balmanoukian A Loriot Y, et al: Atezolizumab in patients with locally advanced and metastatic urothelial carcinoma who have progressed following treatment with platinum-based chemotherapy: A single-arm, multicentre, phase 2 trial. Lancet 387: 1909-1920, 2016.

40. Balar AV, Galsky MD, Rosenberg JE, Powles T, Petrylak DP, Bellmunt J, Loriot Y, Necchi A, Hoffman-Censits J, PerezGracia JL, et al: Atezolizumab as first-line treatment in cisplatin-ineligible patients with locally advanced and metastatic urothelial carcinoma: A single-arm, multicentre, phase 2 trial. Lancet 389: 67-76, 2017.

41. Petrylak DP, Powles T, Bellmunt J, Braiteh F, Loriot Y, Morales-Barrera R, Burris HA, Kim JW, Ding B, Kaiser C, et al: Atezolizumab (MPDL3280A) monotherapy for patients with metastatic urothelial cancer: Long-term outcomes from a phase 1 study. JAMA Oncol 4: 537-544, 2018.

42. Socinski MA, Jotte RM, CappuzzoF, OrlandiF, Stroyakovskiy D, Nogami N, Rodriguez-Abreu D, Moro-Sibilot D, Thomas CA, Barlesi F, et al: Atezolizumab for first-line treatment of metastatic Nonsquamous NSCLC. N Engl J Med 378: 2288-2301, 2018.

43. Powles T, O'Donnell PH, Massard C, Arkenau HT, Friedlander TW, Hoimes CJ, Lee JL, Ong M, Sridhar SS, Vogelzang NJ, et al: Efficacy and safety of durvalumab in locally advanced or metastatic urothelial carcinoma: Updated results from a phase 1/2 open-label study. JAMA Oncol 3: e172411, 2017.

44. Taube JM, Klein A, Brahmer JR, Xu H, Pan X, Kim JH, Chen L, Pardoll DM, Topalian SL and Anders RA: Association of PD-1, PD-1 ligands, and other features of the tumor immune microenvironment with response to anti-PD-1 therapy. Clin Cancer Res 20: 5064-5074, 2014.

45. Chen G, Huang AC, Zhang W, Zhang G, Wu M, Xu W, Yu Z, Yang J, Wang B, Sun H, et al: Exosomal PD-L1 contributes to immunosuppression and is associated with anti-PD-1 response. Nature 560: 382-386, 2018

46. Okuma Y, Wakui H, Utsumi H, Sagawa Y, Hosomi Y, Kuwano K and Homma S: Soluble programmed cell death ligand 1 as a novel biomarker for nivolumab therapy for non-small-cell lung cancer. Clin Lung Cancer 19: 410-417.e1, 2018.

47. Ritprajak P and Azuma M: Intrinsic and extrinsic control of expression of the immunoregulatory molecule PD-L1 in epithelial cells and squamous cell carcinoma. Oral Oncol 51: 221-228, 2015.

48. Brahmer JR, Tykodi SS, Chow LQ, Hwu WJ, Topalian SL, Hwu P, Drake CG, Camacho LH, Kauh J, Odunsi K, et al: Safety and activity of anti-PD-L1 antibody in patients with advanced cancer. N Engl J Med 366: 2455-2465, 2012.

49. You W, Li L, Sun D, Liu X, Xia Z, Xue S, Chen B, Qin H, Ai J and Jiang H: Farnesoid $X$ receptor constructs an immunosuppressive microenvironment and sensitizes FXR ${ }^{\text {high }}$ PD-L1 $1^{\text {low }}$ NSCLC to Anti-PD-1 immunotherapy. Cancer Immunol Res 7: 990-1000, 2019.

50. Ratcliffe MJ, Sharpe A, Barker C, Scorer P and Walker J: Abstract LB-094: A comparative study of PD-L1 diagnostic assays and the classification of patients as PD-L1 positive and PD-L1 negative. Cancer Res 76 (14 Suppl): LB-094-LB-094, 2016.

51. Fujimoto D, Yamashita D, Fukuoka J, Kitamura Y, Hosoya K, Kawachi H, Sato Y, Nagata K, Nakagawa A, Tachikawa R, et al: Comparison of PD-L1 assays in non-small cell lung cancer: 22C3 pharmDx and SP263. Anticancer Res 38: 6891-6895, 2018.

52. Lim JS, Sundar R, Chenard-Poirier M, Lopez J and Yap TA: Emerging biomarkers for PD-1 pathway cancer therapy. Biomark Med 11: 53-67, 2017.

53. Noman MZ and Chouaib S: Targeting hypoxia at the forefront of anticancer immune responses. Oncoimmunology 3: e954463, 2014.

54. Gowrishankar K, Gunatilake D, Gallagher SJ, Tiffen J, Rizos H and Hersey P: Inducible but not constitutive expression of PD-L1 in human melanoma cells is dependent on activation of NF- $\kappa B$. PLoS One 10: e0123410, 2015. 
55. Liu J, Hamrouni A, Wolowiec D, Coiteux V, Kuliczkowski K, Hetuin D, Saudemont A and Quesnel B: Plasma cells from multiple myeloma patients express B7-H1 (PD-L1) and increase expression after stimulation with IFN-\{gamma\} and TLR ligands via a MyD88-, TRAF6-, and MEK-dependent pathway. Blood 110: 296-304, 2007.

56. Lee SJ, Jang BC, Lee SW, Yang YI, Suh SI, Park YM, Oh S, Shin JG, Yao S, Chen L, et al: Interferon regulatory factor-1 is prerequisite to the constitutive expression and IFN-gamma-induced upregulation of B7-H1 (CD274). FEBS Lett 580: 755-762, 2006.

57. Kondo A, Yamashita T, Tamura H, Zhao W, Tsuji T, Shimizu M, Shinya E, Takahashi H, Tamada K, Chen L, et al: Interferon-gamma and tumor necrosis factor-alpha induce an immunoinhibitory molecule, B7-H1, via nuclear factor-kappaB activation in blasts in myelodysplastic syndromes. Blood 116: $1124-1131,2010$

58. Jin YH, Hou W, Kang HS, Koh CS and Kim BS: The role of interleukin- 6 in the expression of PD-1 and PDL-1 on central nervous system cells following infection with Theiler's murine encephalomyelitis virus. J Virol 87: 11538-11551, 2013.

59. Xiong HY, Ma TT, Wu BT, Lin Y and Tu ZG: IL-12 regulates B7-H1 expression in ovarian cancer-associated macrophages by effects on NF- $\kappa \mathrm{B}$ signalling. Asian Pac J Cancer Prev 15 5767-5772, 2014

60. Akbay EA, Koyama S, Carretero J, Altabef A, Tchaicha JH, Christensen CL, Mikse OR, Cherniack AD, Beauchamp EM, Pugh TJ, et al: Activation of the PD-1 pathway contributes to immune escape in EGFR-driven lung tumors. Cancer Discov 3 $1355-1363,2013$.

61. Hecht M, Buttner-Herold M, Erlenbach-Wunsch K, Haderlein M, Croner R, Grutzmann R, Hartmann A, Fietkau R and Distel LV: PD-L1 is upregulated by radiochemotherapy in rectal adenocarcinoma patients and associated with a favourable prognosis. Eur J Cancer 65: 52-60, 2016

62. Katsuya Y, Horinouchi H, Asao T, Kitahara S, Goto Y, Kanda S, Fujiwara Y, Nokihara H, Yamamoto N, Watanabe S, et al: Expression of programmed death 1 (PD-1) and its ligand (PD-L1) in thymic epithelial tumors: Impact on treatment efficacy and alteration in expression after chemotherapy. Lung Cancer 99 4-10, 2016.

63. Takamori S, Takada K, Tagawa T, Toyokawa G, Hirai F, Yamashita N, Okamoto T, Oki E, Yoshizumi T, Oda Y, et al: Differences in PD-L1 expression on tumor and immune cells between lung metastases and corresponding primary tumors. Surg Oncol 27: 637-641, 2018.

64. Kandoth C, McLellan MD, Vandin F, Ye K, Niu B, Lu C, Xie M Zhang Q, McMichael JF, Wyczalkowski MA, et al: Mutational landscape and significance across 12 major cancer types. Nature 502: 333-339, 2013.

65. Alexandrov LB, Nik-Zainal S, Wedge DC, Aparicio SA, Behjati S, Biankin AV, Bignell GR, Bolli N, Borg A, Borresen-Dale AL, et al: Signatures of mutational processes in human cancer. Nature 500: 415-421, 2013.

66. Herbst RS, Soria JC, Kowanetz M, Fine GD, Hamid O, Gordon MS, Sosman JA, McDermott DF, Powderly JD, Gettinger SN, et al: Predictive correlates of response to the anti-PD-L1 antibody MPDL3280A in cancer patients. Nature 515: 563-567, 2014

67. Rizvi NA, Hellmann MD, Snyder A, Kvistborg P, Makarov V, Havel JJ, Lee W, Yuan J, Wong P, Ho TS, et al: Cancer immunology. Mutational landscape determines sensitivity to PD-1 blockade in non-small cell lung cancer. Science 348: 124-128, 2015.

68. Forde PM, Chaft JE, Smith KN, Anagnostou V, Cottrell TR, Hellmann MD, Zahurak M, Yang SC, Jones DR, Broderick S, et al Neoadjuvant PD-1 blockade in resectable lung cancer. N Engl J Med 378: 1976-1986, 2018

69. Wang Z, Duan J, Cai S, Han M, Dong H, Zhao J, Zhu B, Wang S, Zhuo M, Sun J, et al: Assessment of blood tumo mutational burden as a potential biomarker for immunotherapy in patients with non-small cell lung cancer with use of a next-generation sequencing cancer gene panel. JAMA Oncol 5: 696-702, 2019.

70. Lipson EJ, Sharfman WH, Drake CG, Wollner I, Taube JM, Anders RA, Xu H, Yao S, Pons A, Chen L, et al: Durable cancer regression off-treatment and effective reinduction therapy with an anti-PD-1 antibody. Clin Cancer Res 19: 462-468, 2013.

71. Li GM: Mechanisms and functions of DNA mismatch repair. Cell Res 18: 85-98, 2008
72. Le DT, Uram JN, Wang $\mathrm{H}$, Bartlett BR, Kemberling $\mathrm{H}$, Eyring AD, Skora AD, Luber BS, Azad NS, Laheru D, et al: PD-1 blockade in tumors with mismatch-repair deficiency. N Engl J Med 372: 2509-2520, 2015.

73. Le DT, Durham JN, Smith KN, Wang H, Bartlett BR, Aulakh LK, Lu S, Kemberling H, Wilt C, Luber BS, et al: Mismatch repair deficiency predicts response of solid tumors to PD-1 blockade. Science 357: 409-413, 2017.

74. Schumacher TN and Schreiber RD: Neoantigens in cancer immunotherapy. Science 348: 69-74, 2015.

75. McGranahan N, Furness AJ, Rosenthal R, Ramskov S, Lyngaa R, Saini SK, Jamal-Hanjani M, Wilson GA, Birkbak NJ, Hiley CT, et al: Clonal neoantigens elicit T cell immunoreactivity and sensitivity to immune checkpoint blockade. Science 351 : 1463-1469, 2016

76. Van Allen EM, Golay HG, Liu Y, Koyama S, Wong K, Taylor-Weiner A, Giannakis M, Harden M, Rojas-Rudilla V, Chevalier A, et al: Long-term benefit of PD-L1 blockade in lung cancer associated with JAK3 activation. Cancer Immunol Res 3: 855-863, 2015.

77. Azuma K, Ota K, Kawahara A, Hattori S, Iwama E, Harada T, Matsumoto K, Takayama K, Takamori S, Kage M, et al: Association of PD-L1 overexpression with activating EGFR mutations in surgically resected nonsmall-cell lung cancer. Ann Oncol 25: 1935-1940, 2014.

78. Parsa AT, Waldron JS, Panner A, Crane CA, Parney IF, Barry JJ, Cachola KE, Murray JC, Tihan T, Jensen MC, et al: Loss of tumor suppressor PTEN function increases B7-H1 expression and immunoresistance in glioma. Nat Med 13: 84-88, 2007.

79. Marzec M, Zhang Q, Goradia A, Raghunath PN, Liu X, Paessler M, Wang HY, Wysocka M, Cheng M, Ruggeri BA, et al: Oncogenic kinase NPM/ALK induces through STAT3 expression of immunosuppressive protein CD274 (PD-L1, B7-H1). Proc Natl Acad Sci USA 105: 20852-20857, 2008.

80. Yadav M, Jhunjhunwala S, Phung QT, Lupardus P, Tanguay J, Bumbaca S, Franci C, Cheung TK, Fritsche J, Weinschenk T, et al: Predicting immunogenic tumour mutations by combining mass spectrometry and exome sequencing. Nature 515: 572-576, 2014.

81. Zaretsky JM, Garcia-Diaz A, Shin DS, Escuin-Ordinas H, Hugo W, Hu-Lieskovan S, Torrejon DY, Abril-Rodriguez G, Sandoval S, Barthly L, et al: Mutations associated with acquired resistance to PD-1 blockade in melanoma. N Engl J Med 375: 819-829, 2016.

82. Skoulidis F, Goldberg ME, Greenawalt DM, Hellmann MD, Awad MM, Gainor JF, Schrock AB, Hartmaier RJ, Trabucco SE, Gay L, et al: STK11/LKB1 mutations and PD-1 inhibitor resistance in KRAS-mutant lung adenocarcinoma. Cancer Discov 8: $822-835,2018$.

83. Chen F, Zhuang X, Lin L, Yu P, Wang Y, Shi Y, Hu G and Sun Y: New horizons in tumor microenvironment biology: Challenges and opportunities. BMC Med 13: 45, 2015.

84. Mantovani A, Allavena P, Sica A and Balkwill F: Cancer-related inflammation. Nature 454: 436-444, 2008.

85. Yang L, Pang Y and Moses HL: TGF-beta and immune cells: An important regulatory axis in the tumor microenvironment and progression. Trends Immunol 31: 220-227, 2010.

86. Pauken KE and Wherry EJ: Overcoming T cell exhaustion in infection and cancer. Trends Immunol 36: 265-276, 2015.

87. Li HY, McSharry M, Bullock B, Nguyen TT, Kwak J, Poczobutt JM, Sippel TR, Heasley LE, Weiser-Evans MC, Clambey ET, et al: The tumor microenvironment regulates sensitivity of murine lung tumors to PD-1/PD-L1 antibody blockade. Cancer Immunol Res 5: 767-777, 2017.

88. Smyth MJ, Ngiow SF, Ribas A and Teng MW: Combination cancer immunotherapies tailored to the tumour microenvironment. Nat Rev Clin Oncol 13: 143-158, 2016.

89. Tumeh PC, Harview CL, Yearley JH, Shintaku IP, Taylor EJ, Robert L, Chmielowski B, Spasic M, Henry G, Ciobanu V, et al: PD-1 blockade induces responses by inhibiting adaptive immune resistance. Nature 515: 568-571, 2014.

90. Chen PL, Roh W, Reuben A, Cooper ZA, Spencer CN, Prieto PA, Miller JP, Bassett RL, Gopalakrishnan V, Wani K, et al: Analysis of immune signatures in longitudinal tumor samples yields insight into biomarkers of response and mechanisms of resistance to immune checkpoint blockade. Cancer Discov 6: 827-837, 2016

91. Daud AI, Loo K, Pauli ML, Sanchez-Rodriguez R, Sandoval PM, Taravati K, Tsai K, Nosrati A, Nardo L, Alvarado MD, et al: Tumor immune profiling predicts response to anti-PD-1 therapy in human melanoma. J Clin Invest 126: 3447-3452, 2016. 
92. Kim R, Keam B, Kim S, Kim M, Kim SH, Kim JW, Kim YJ, Kim TM, Jeon YK, Kim DW, et al: Differences in tumor microenvironments between primary lung tumors and brain metastases in lung cancer patients: Therapeutic implications for immune checkpoint inhibitors. BMC Cancer 19: 19, 2019.

93. Chen DS and Mellman I: Elements of cancer immunity and the cancer-immune set point. Nature 541: 321-330, 2017.

94.Kim CG, Jang M, Kim Y, Leem G, Kim KH, Lee H, Kim TS, Choi SJ, Kim HD, Han JW, et al: VEGF-A drives TOX-dependent $\mathrm{T}$ cell exhaustion in anti-PD-1-resistant microsatellite stable colorectal cancers. Sci Immunol 4 eaay0555, 2019.

95. Ngiow SF, Young A, Jacquelot N, Yamazaki T, Enot D, Zitvogel L and Smyth MJ: A threshold level of intratumor CD8+ T-cell PD1 expression dictates therapeutic response to Anti-PD1. Cancer Res 75: 3800-3811, 2015

96. Davis RJ, Moore EC, Clavijo PE, Friedman J, Cash H, Chen Z, Silvin C, Van Waes C and Allen C: Anti-PD-L1 efficacy Can $\mathrm{Be}$ enhanced by inhibition of myeloid-derived suppressor cells with a selective inhibitor of $\mathrm{PI} 3 \mathrm{~K} \delta / \gamma$. Cancer Res 77 2607-2619, 2017.

97. Mao Y, Eissler N, Blanc KL, Johnsen JI, Kogner P and Kiessling R: Targeting suppressive myeloid cells potentiates checkpoint inhibitors to control spontaneous neuroblastoma. Clin Cancer Res 22: 3849-3859, 2016.

98. Stone TW and Darlington LG: Endogenous kynurenines as targets for drug discovery and development. Nat Rev Drug Discov 1: 609-620, 2002.

99. Llosa NJ, Cruise M, Tam A, Wicks EC, Hechenbleikner EM, Taube JM, Blosser RL, Fan H, Wang H, Luber BS, et al: The vigorous immune microenvironment of microsatellite instable colon cancer is balanced by multiple counter-inhibitory checkpoints. Cancer Discov 5: 43-51, 2015.

100. Higgs BW, Robbins PB, Blake-Haskins JA, Zhu W, Morehouse C, Brohawn PZ, Rebelatto MC, Yao Y, Jin X, Shi L and Ranade K 15LBA High tumoral IFN $\gamma$ mRNA, PD-L1 protein, and combined IFN $\gamma$ mRNA/PD-L1 protein expression associates with response to durvalumab (anti-PD-L1) monotherapy in NSCLC patients. Eur J Cancer 51 (Suppl): S717, 2015.

101. Ascierto ML, McMiller TL, Berger AE, Danilova L, Anders RA, Netto GJ, Xu H, Pritchard TS, Fan J, Cheadle C, et al: The intratumoral balance between metabolic and immunologic gene expression is associated with Anti-PD-1 response in patients with renal cell carcinoma. Cancer Immunol Res 4: 726-733, 2016.

102. Francisco LM, Salinas VH, Brown KE, Vanguri VK, Freeman GJ, Kuchroo VK and Sharpe AH: PD-L1 regulates the development, maintenance, and function of induced regulatory T cells. J Exp Med 206: 3015-3029, 2009.

103. Ding ZC, Lu X, Yu M, Lemos H, Huang L, Chandler P, Liu K, Walters M, Krasinski A, Mack M, et al: Immunosuppressive myeloid cells induced by chemotherapy attenuate antitumor CD4+ T-cell responses through the PD-1-PD-L1 axis. Cancer Res 74: 3441-3453, 2014

104. Platten M, Wick W and Van den Eynde BJ: Tryptophan catabolism in cancer: Beyond IDO and tryptophan depletion. Cancer Res 72: 5435-5440, 2012

105. Ayers M, Lunceford J, Nebozhyn M, Murphy E, Loboda A, Kaufman DR, Albright A, Cheng JD, Kang SP, Shankaran V, et al: IFN- $\gamma$-related mRNA profile predicts clinical response to PD-1 blockade. J Clin Invest 127: 2930-2940, 2017.

106.Zhang X, Zeng Y, Qu Q, Zhu J, Liu Z, Ning W, Zeng H, Zhang N, Du W, Chen C, et al: PD-L1 induced by IFN- $\gamma$ from tumor-associated macrophages via the JAK/STAT3 and PI3K/AKT signaling pathways promoted progression of lung cancer. Int J Clin Oncol 22: 1026-1033, 2017.

107. Quandt D, Jasinski-Bergner S, Muller U, Schulze B and Seliger B: Synergistic effects of IL-4 and TNFa on the induction of B7-H1 in renal cell carcinoma cells inhibiting allogeneic T cell proliferation. J Transl Med 12: 151, 2014

108. Ni XY, Sui HX, Liu Y, Ke SZ, Wang YN and Gao FG: TGF- $\beta$ of lung cancer microenvironment upregulates $\mathrm{B} 7 \mathrm{H} 1$ and GITRL expression in dendritic cells and is associated with regulatory T cell generation. Oncol Rep 28: 615-621, 2012

109. Rodriguez-Garcia M, Porichis F, de Jong OG, Levi K, Diefenbach TJ, Lifson JD, Freeman GJ, Walker BD, Kaufmann DE and Kavanagh DG: Expression of PD-L1 and PD-L2 on human macrophages is up-regulated by HIV-1 and differentially modulated by IL-10. J Leukoc Biol 89: 507-515, 2011
110. Kondou R, Iizuka A, Nonomura C, Miyata H, Ashizawa T, Nagashima T, Ohshima K, Urakami K, Kusuhara M, Yamaguchi $\mathrm{K}$, et al: Classification of tumor microenvironment immune types based on immune response-associated gene expression. Int J Oncol 54: 219-228, 2019.

111. Spranger S, Spaapen RM, Zha Y, Williams J, Meng Y, Ha TT and Gajewski TF: Up-regulation of PD-L1, IDO, and T(regs) in the melanoma tumor microenvironment is driven by CD8(+) T cells. Sci Transl Med 5: 200ra116, 2013.

112. Zhao J, Wen X, Tian L, Li T, Xu C, Wen X, Melancon MP, Gupta S, Shen B, Peng W, et al: Irreversible electroporation reverses resistance to immune checkpoint blockade in pancreatic cancer. Nat Commun 10: 899, 2019.

113. Liu P, Zhao L, Pol J, Levesque S, Petrazzuolo A, Pfirschke C, Engblom C, Rickelt S, Yamazaki T, Iribarren K, et al: Crizotinib-induced immunogenic cell death in non-small cell lung cancer. Nat Commun 10: 1486, 2019.

114. Nikolich-Zugich J, Slifka MK and Messaoudi I: The many important facets of T-cell repertoire diversity. Nat Rev Immunol 4: 123-132, 2004.

115. Ruggiero E, Nicolay JP, Fronza R, Arens A, Paruzynski A, Nowrouzi A, Urenden G, Lulay C, Schneider S, Goerdt S, et al: High-resolution analysis of the human T-cell receptor repertoire. Nat Commun 6: 8081, 2015.

116. Zheng Y, Wang T, Tu X, Huang Y, Zhang H, Tan D, Jiang W, Cai S, Zhao P, Song R, et al: Gut microbiome affects the response to anti-PD-1 immunotherapy in patients with hepatocellular carcinoma. J Immunother Cancer 7: 193, 2019.

117. Sunakawa Y, Inoue E, Matoba R, Kawakami H, Sato Y, Nakajima TE, Muro K, Ichikawa W and Fujii M: DELIVER (JACCRO GC-08) trial: Discover novel host-related immune-biomarkers for nivolumab in advanced gastric cancer. Future Oncol 15: 2441-2447, 2019.

118. Matson V, Fessler J, Bao R, Chongsuwat T, Zha Y, Alegre ML, Luke JJ and Gajewski TF: The commensal microbiome is associated with anti-PD-1 efficacy in metastatic melanoma patients. Science 359: 104-108, 2018.

119. Jin Y, Dong H, Xia L, Yang Y, Zhu Y, Shen Y, Zheng H, Yao C, Wang $\mathrm{Y}$ and $\mathrm{Lu} \mathrm{S}$ : The diversity of gut microbiome is associated with favorable responses to anti-programmed death 1 immunotherapy in Chinese patients with NSCLC. J Thorac Oncol 14: 1378-1389, 2019

120. Ivanov II and Littman DR: Modulation of immune homeostasis by commensal bacteria. Curr Opin Microbiol 14: 106-114, 2011.

121. Sivan A, Corrales L,Hubert N, Williams JB,Aquino-Michaels K, Earley ZM, Benyamin FW, Lei YM, Jabri B, Alegre ML, et al: Commensal Bifidobacterium promotes antitumor immunity and facilitates anti-PD-L1 efficacy. Science 350: 1084-1089, 2015.

122. Vetizou M, Pitt JM, Daillere R, Lepage P, Waldschmitt N, Flament C, Rusakiewicz S, Routy B, Roberti MP, Duong CP, et al: Anticancer immunotherapy by CTLA-4 blockade relies on the gut microbiota. Science 350: 1079-1084, 2015.

123. Dong M, Meng Z, Kuerban K, Qi F, Liu J, Wei Y, Wang Q, Jiang S, Feng $M$ and Ye L: Diosgenin promotes antitumor immunity and PD-1 antibody efficacy against melanoma by regulating intestinal microbiota. Cell Death Dis 9: 1039, 2018

124. Weide B, Martens A, Hassel JC, Berking C, Postow MA, Bisschop K, Simeone E, Mangana J, Schilling B, Di Giacomo AM, et al: Baseline biomarkers for outcome of melanoma patients treated with pembrolizumab. Clin Cancer Res 22: 5487-5496, 2016

125. Zer A, Sung MR, Walia P, Khoja L, Maganti M, Labbe C, Shepherd FA, Bradbury PA, Feld R, Liu G, et al: Correlation of neutrophil to lymphocyte ratio and absolute neutrophil count with outcomes with PD-1 axis inhibitors in patients with advanced non-small-cell lung cancer. Clin Lung Cancer 19: 426-434.e1, 2018

126. Diem S, Kasenda B, Spain L, Martin-Liberal J, Marconcini R, Gore M and Larkin J: Serum lactate dehydrogenase as an early marker for outcome in patients treated with anti-PD-1 therapy in metastatic melanoma. Br J Cancer 114: 256-261, 2016.

127. Gibney GT, Kudchadkar RR, DeConti RC, Thebeau MS, Czupryn MP, Tetteh L, Eysmans C, Richards A, Schell MJ, Fisher KJ, et al: Safety, correlative markers, and clinical results of adjuvant nivolumab in combination with vaccine in resected high-risk metastatic melanoma. Clin Cancer Res 21: 712-720, 2015. 
128. Niemeijer AN, Leung D, Huisman MC, Bahce I, Hoekstra OS, van Dongen G, Boellaard R, Du S, Hayes W, Smith R, et al: Whole body PD-1 and PD-L1 positron emission tomography in patients with non-small-cell lung cancer. Nat Commun 9: 4664, 2018.

129. Bensch F, van der Veen EL, Lub-de Hooge MN, JorritsmaSmit A, Boellaard R, Kok IC, Oosting SF, Schroder CP, Hiltermann TJN, van der Wekken AJ, et al: ${ }^{89} \mathrm{Zr}$-atezolizumab imaging as a non-invasive approach to assess clinical response to PD-L1 blockade in cancer. Nat Med 24: 1852-1858, 2018.

130. Sun R, Limkin EJ, Vakalopoulou M, Dercle L, Champiat S, Han SR, Verlingue L, Brandao D, Lancia A, Ammari S, et al: A radiomics approach to assess tumour-infiltrating CD8 cells and response to anti-PD-1 or anti-PD-L1 immunotherapy: An imaging biomarker, retrospective multicohort study. Lancet Oncol 19: 1180-1191, 2018

131. Joyce JA and Fearon DT: T cell exclusion, immune privilege, and the tumor microenvironment. Science 348: 74-80, 2015
132. Kluger HM,Zito CR, Barr ML, Baine MK, Chiang VL, Sznol M, Rimm DL, Chen L and Jilaveanu LB: Characterization of PD-L1 expression and associated T-cell infiltrates in metastatic melanoma samples from variable anatomic sites. Clin Cancer Res 21: 3052-3060, 2015.

133. Rooney MS, Shukla SA, Wu CJ, Getz G and Hacohen N: Molecular and genetic properties of tumors associated with local immune cytolytic activity. Cell 160: 48-61, 2015.

134. Feng Z, Puri S, Moudgil T, Wood W, Hoyt CC, Wang C, Urba WJ, Curti BD, Bifulco CB and Fox BA: Multispectral imaging of formalin-fixed tissue predicts ability to generate tumor-infiltrating lymphocytes from melanoma. J Immunother Cancer 3: 47, 2015.

This work is licensed under a Creative Commons

Attribution-NonCommercial-NoDerivatives 4.0 International (CC BY-NC-ND 4.0) License. 